OPEN ACCESS

Edited by:

Nour Eissa

University of Manitoba, Canada

Reviewed by:

Stefa-Adrian Strungaru,

Alexandru loan Cuza University,

Romania

Vanessa Labrada Martagón,

Universidad Autónoma de San Luis

Potosí, Mexico

Jianmin Zhao,

Yantai Institute of Coastal Zone

Research (CAS), China

Valbona Aliko,

University of Tirana, Albania

*Correspondence:

Wei Huang

huangwei8182@gmail.com

Specialty section:

This article was submitted to

Aquatic Physiology,

a section of the journal

Frontiers in Physiology

Received: 31 May 2018

Accepted: 21 September 2018

Published: 10 October 2018

Citation:

Wu F, Huang W, Liu Q, Xu X, Zeng J, Cao L, Hu J, Xu X, Gao Y and Jia $S$ (2018) Responses of Antioxidant

Defense and Immune Gene

Expression in Early Life Stages of Large Yellow Croaker (Pseudosciaena

crocea) Under Methyl Mercury

Exposure. Front. Physiol. 9:1436.

doi: 10.3389/fphys.2018.01436

\section{Responses of Antioxidant Defense and Immune Gene Expression in Early Life Stages of Large Yellow Croaker (Pseudosciaena crocea) Under Methyl Mercury Exposure}

\author{
Fangzhu $W u^{1}$, Wei Huang ${ }^{1 *}$, Qiang Liu' ${ }^{1}$, Xiaoqun $X u^{1}$, Jiangning Zeng ${ }^{1,2}$, Liang $\mathrm{CaO}^{3}$, \\ Ji Hu${ }^{1}$, Xudan Xu' ${ }^{1}$, Yuexin Gao ${ }^{1}$ and Shenghua Jia ${ }^{1,4}$ \\ 1 Key Laboratory of Marine Ecosystem and Biogeochemistry, Second Institute of Oceanography, State Oceanic \\ Administration, Hangzhou, China, ${ }^{2}$ Ocean College, Zhejiang University, Hangzhou, China, ${ }^{3}$ Institute of Oceanology, Chinese \\ Academy of Sciences, Qingdao, China, ${ }^{4}$ Zhejiang Surveying Institute of Estuary and Coast, Hangzhou, China
}

Early life stages of marine organisms are the most sensitive stages to environment stressors including pollutants. In order to understand the toxicological effects induced by MeHg exposure on juveniles of large yellow croaker (Pseudosciaena crocea), a toxicity test was performed wherein fish were exposed to sub-lethal concentrations of $\mathrm{MeHg}$ under laboratory conditions $\left(18 \pm 1^{\circ} \mathrm{C} ; 26 \pm 1\right.$ in salinity). After 30 days of $0-4.0 \mu \mathrm{g} \mathrm{L}^{-1} \mathrm{MeHg}$ exposure, SOD activity was significantly decreased in the $0.25,1.0$, and $4.0 \mu \mathrm{g} \mathrm{L}^{-1}$ treatments; while CAT activity was significantly increased in the $4.0 \mu \mathrm{g} \mathrm{L}^{-1}$ treatments; GSH level, GPx activity were significantly elevated in the $4.0 \mu \mathrm{g} \mathrm{L}^{-1}$ treatments, respectively. Meanwhile, malondialdehyde content was also significantly increased in the 1.0 and $4.0 \mu \mathrm{g} \mathrm{L}^{-1}$ treatments with respect to the control. Acetylcholinesterase activity was significantly decreased by $18.3,25.2$, and $21.7 \%$ in the $0.25,1.0$, and $4.0 \mu \mathrm{g} \mathrm{L}^{-1}$ treatments, respectively. The expression of TCTP, GST3, Hsp70, Hsp27 mRNA were all up-regulated in juveniles with a dose-dependent manner exposed to MeHg. These results suggest that large yellow croaker juveniles have the potential to regulate the levels of antioxidant enzymes and initiate immune response in order to protect fish to some extent from oxidative stress induced by MeHg.

Keywords: large yellow croaker, juvenile, MeHg exposure, antioxidant defense system, mRNA expression

\section{INTRODUCTION}

Mercury $(\mathrm{Hg})$ is one of the most toxic metals in the global environment which widely exists in lithosphere, hydrosphere, atmosphere and biosphere, its main anthropogenic sources are urban and industrial emissions, agricultural materials, mining, and combustion (Zhang and Wong, 2007). In marine ecosystems, $\mathrm{Hg}$ exists in a variety of forms such as inorganic salts, metallic elements, and organic compounds (Lee et al., 2017b). The most toxic form of $\mathrm{Hg}$ is methyl mercury (MeHg) which is mainly synthetized through microbial processes and biochemical reactions in aquatic ecosystems (Fitzgerald and Mason, 1997). MeHg is the most highly absorbable form of $\mathrm{Hg}$ and it is primarily bioaccumulated in aquatic life, the percentage of $\mathrm{MeHg}$ is about $72-100 \%$ to total $\mathrm{Hg}$ 
in fish (Arlenyetal., 2007; Zhang and Wong, 2007). Bioaccumulation of $\mathrm{MeHg}$ in fish rests with the trophic level as well as its age, length, or weight (Zhang and Wong, 2007), the concentration of MeHg in top predator fish could be three orders of that in ambient waters (Morel et al., 1998). As the ultimate predator at the top of food chain, human beings also have high risk exposed to $\mathrm{Hg}$, primarily by eating fish contain $\mathrm{MeHg}$ (Squadrone et al., 2015).

$\mathrm{MeHg}$ is known as its neurotoxicity which can damage the central nervous system (CNS) of organisms (Kaur et al., 2006). It can penetrate the blood-brain barrier easily with L-type amino acid transporters such as the $\mathrm{MeHg}$-L-cysteine complex (Aschner, 1989). Moreover, MeHg has been proven to injure immune system, alter enzymes system, induce DNA damage as well (Cambier et al., 2009; Squadrone et al., 2015). For fish, previous studies indicated that $\mathrm{MeHg}$ could affect the gonadal development, reproduction, feeding behavior, and induce oxidative damage (Mozhdeganloo et al., 2015). For example, delayed mortality syndrome appeared in zebrafish (Danio rerio) after embryonic exposure below $20 \mu \mathrm{g} \mathrm{L}^{-1} \mathrm{MeHg}$ (Samson et al., 2001). Besides, mitochondrial bioenergetics can be disturbed in skeletal muscle of adult zebrafish (Danio rerio) by low concentration of MeHg exposure (Cambier et al., 2009). Early life stages (ELSs) have been proved to be particularly sensitive to environment stressors including pollutants (Devlin and Mottet, 1992). Fish exposed to low concentrations of pollutants during their ELS may induce injury on biology and behavior to their later developmental stages (Devlin, 2006). Thus, the toxicity evaluation derived from these ELS experiments could strongly indicate the range of potential biological effects of toxicant action (Devlin, 2006).

In China, the concentrations of total $\mathrm{Hg}$ ( $\mathrm{THg}$ ) and $\mathrm{MeHg}$ in the surface seawater of northern South China Sea ranged from 0.0008-0.0023 $\mu \mathrm{g} \mathrm{L}^{-1}$ and 0.00005-0.00022 $\mu \mathrm{g} \mathrm{L}^{-1}$ (Fu et al., 2010). While in the Bohai Sea and East China Sea, THg mercury ranged from $0.002-0.15 \mu \mathrm{g} \mathrm{L}^{-1}$ and $0.012-$ $0.071 \mu \mathrm{g} \mathrm{L}^{-1}$, respectively (Huang et al., 2010b). Large yellow croaker (Pseudosciaena crocea) are middle carnivorous fish which mainly distributed in the coastal waters of southeast China (Xu and Liu, 2007; Xia et al., 2013), which used to be the most important commercial fish in China, however, their wild population and resources decreased dramatically since the 1980s (Xu and Liu, 2007). Meanwhile, the pollutants including metals in the waters and sediments of their spawning and nursery grounds in the East China Sea had been overloaded (Wang et al., 2005). Compared with lower carnivorous fish and omnivorous fish, large yellow croaker accumulated higher levels of $\mathrm{THg}$ and $\mathrm{MeHg}$ due to their higher trophic position and larger size. It has been reported that the concentrations of $\mathrm{THg}$ and $\mathrm{MeHg}$ accumulated in large yellow croaker from coasts of East China are 34.4 and $24.9 \mathrm{ng} \mathrm{g}^{-1}$, respectively (Xia et al., 2013). Therefore, biological damages caused by contaminants on reproduction, development, and survival of large yellow croaker have been considered as potential hazards for their wild population deterioration (Wang et al., 2005). However, studies on the toxicity of pollutants to the ELS of large yellow croaker are limited with that of heavy metal exposure being particularly lacking.
In order to better understand the toxicological effects of $\mathrm{MeHg}$ to large yellow croaker, a toxicity test was performed wherein juveniles were exposed to sub-lethal concentrations of $\mathrm{MeHg}$ for 30 days. The specific objectives of the present study were as follows: (1) to elucidate how antioxidants (SOD, CAT, GSH, GPx) responded to $\mathrm{MeHg}$ accumulation to cope with oxidative stress; (2) to determine how lipid peroxidation and acetylcholinesterase (AChE) responded to $\mathrm{MeHg}$ exposure; (3) to evaluate the mRNA expression of genes related to immune response (TCTP, GST3, Hsp70, Hsp27 transcripts) by $\mathrm{MeHg}$ exposure.

\section{MATERIALS AND METHODS}

\section{Experimental Organisms}

This study was carried out in accordance with the recommendations of Second Institute of Oceanograpy, State Oceanic Administration, China. Large yellow croaker juveniles were obtained from Institute of Marine and Fisheries Research of Ningbo, China. The fish were acclimatized in a flow-through pond with filtered seawater (hardness, $6124.6 \pm 272.3 \mathrm{mg} \mathrm{L}^{-1}$ as $\mathrm{CaCO}_{3}$; pH, $8.1 \pm 0.1$; salinity, $28 \pm 1$; dissolved oxygen, $7.5 \pm 0.2 \mathrm{mg} \mathrm{L}^{-1}$; MeHg, $0.00006 \pm 0.00003 \mu \mathrm{g} \mathrm{L}^{-1}$ ) for 2 weeks before they were used in experiments. During acclimation, the fish were fed artificial foods (Tianma Company, Fujian, China) twice a day with a light regime of $14 \mathrm{~L}: 10 \mathrm{D}$. A thermostatcontrolled water bath system was used to maintain the water temperature at $18 \pm 1^{\circ} \mathrm{C}$.

\section{Experimental Procedure}

About 1,000 healthy juvenile fish with similar size were selected randomly and transferred into each of the $300 \mathrm{~L}$ experimental tanks, which were placed randomly in the laboratory with an constant temperature of $18 \pm 1^{\circ} \mathrm{C}$. Fish size $(2.0 \pm 0.2 \mathrm{~cm}$ in total length, $\mathrm{L}_{\mathrm{T}} ; 0.13 \pm 0.04 \mathrm{~g}$ in body weight, $\left.\mathrm{W}_{\mathrm{B}}\right)$ did not significantly differ between replicates or concentrations (ANOVA, $p>0.05$ in all cases). After a $24 \mathrm{~h}$ acclimation period in the experimental tanks without feeding, the fish were exposed to either a blank control $\left(0 \mu \mathrm{g} \mathrm{L}^{-1}\right)$ solution or a MeHg solution of $0.25,1.0$, or $4.0 \mu \mathrm{g} \mathrm{L}^{-1} \mathrm{MeHg}$. Four replicates were performed for each concentration. Each experimental tank was filled with $200 \mathrm{~L}$ of filtered seawater. The fish rearing conditions were identical to those for the acclimation described above. The analyticalreagent methyl mercury chloride $\left(\mathrm{CH}_{3} \mathrm{ClHg}\right.$, purity over $99.5 \%$; CAS No: 115-09-3; Sigma-Aldrich Chemical, Co., United States) was used as the test chemical. A stock solution $\left(1.0 \mathrm{~g} \mathrm{~L}^{-1}\right)$ was prepared by dissolving $\mathrm{CH}_{3} \mathrm{ClHg}$ in deionized water, from which appropriate aliquots were diluted in filtered seawater to obtain the designated concentration in each experimental tank. Oxygen was gently provided by a continuous air-bubbling system. The fish were fed artificial foods to satiety at 9:00, excessive food, dead juveniles were removed and the solution in the experimental tanks was renewed daily with freshly prepared solution of the same $\mathrm{MeHg}$ concentration at 15:00 during the test. The test was terminated 30 days after exposure began. The test solutions were sampled from each experimental beaker at the beginning, the intermediate and the end of the tests, respectively. Test solutions 
were measured using gas chromatography-mass spectrometry (GC-MS) (Agilent 6890/5973; United States). The measured concentrations fell within the range of $80-120 \%$ of the nominal concentrations.

At the end of test, 100 fish were randomly sampled from each experimental tank. They were freshly weighed to the nearest $0.1 \mathrm{~g}\left(\mathrm{~W}_{\mathrm{B}}\right)$ and measured to the nearest $0.1 \mathrm{~cm}\left(\mathrm{~L}_{\mathrm{T}}\right)$ for growth determination. Fish size $\left(4.06 \pm 0.61 \mathrm{~cm}\right.$ in total length, $\mathrm{L}_{\mathrm{T}}$; $0.47 \pm 0.17 \mathrm{~g}$ in body weight, $\left.\mathrm{W}_{\mathrm{B}}\right)$ did not significantly differ between replicates or concentrations (ANOVA, $p>0.05$ in all cases). After that, the fish were frozen immediately in freezing tube in the $-80^{\circ} \mathrm{C}$ refrigerator (Thermo Scientific 902-ULTS). The tissues were then immediately stored in acid-rinsed vials in liquid nitrogen awaiting the determination of antioxidant and the expression of mRNA.

\section{Antioxidant Enzymes and Lipid Peroxides Determination}

Samples used for enzymes determination were thoroughly washed with ice-cold physiological salt solution $(0.9 \% \mathrm{NaCl})$, surface dried with absorbent paper and accurate weighted. Then the samples and $10 \mathrm{mM}$ ice-cold Tris- $\mathrm{HCl}$ buffer solution $(\mathrm{pH}$ 7.4) at the ratio of 1: 9 by weight to volume were transferred into a glass tube and homogenized by a homogenizer (IKA, Germany) with ice bath. The tissue fluid was centrifuged for $10 \mathrm{~min}$ at $12000 \mathrm{rpm}$ at $4^{\circ} \mathrm{C}$ (Eppendorf 5804R, Hamburg, Germany). The supernatants were collected for further analysis.

\section{Superoxide Dismutase (SOD) Activity}

The SOD activity was determined by method of pyrogallol autooxidation (Marklund and Marklund, 1974). Add $8.7 \mathrm{~mL}$ of $50 \mathrm{mM}$ phosphoric acid buffer ( $\mathrm{pH} \mathrm{8.2)}$ and $0.25 \mathrm{~mL}$ of $20 \mathrm{mM}$ pyrogallol to $50 \mu \mathrm{L}$ supernatant at $25^{\circ} \mathrm{C}$ and the determination wavelength is $325 \mathrm{~nm}$. One SOD activity unit was defined as the amount of enzyme exhibiting 50\% inhibition of the autooxidation rate of $0.1 \mathrm{mM}$ pyrogallol per minute in $1 \mathrm{~mL}$ solution at $25^{\circ} \mathrm{C}$. Results were expressed as $\mathrm{U} \mathrm{mg}^{-1} \mathrm{Pr}$.

\section{Catalase (CAT) Activity}

Activity of CAT was measured with reference to the method of Beers and Sizer (1952). Add $1.9 \mathrm{~mL}$ of $50 \mathrm{mM}$ phosphoric acid buffer $(\mathrm{pH} 7.0)$ and $1.0 \mathrm{~mL}$ of $5 \mathrm{mM} \mathrm{H}_{2} \mathrm{O}_{2}$ to $100 \mu \mathrm{L}$ supernatant and the determination wavelength is $240 \mathrm{~nm}$. One CAT activity unit was defined as the amount of enzyme that catalyzed the degradation of $1 \mu \mathrm{mol} \mathrm{H}_{2} \mathrm{O}_{2}$ per minute and results were expressed as $\mathrm{U} \mathrm{mg}^{-1} \mathrm{Pr}$.

\section{Glutathione (GSH) Content}

Glutathione content was measured with reference to the method of Hissin and Hilf (1976). Add $4 \mathrm{~mL}$ phosphoric acid-EDTA buffer ( $\mathrm{pH} 8.0$ ) to $1 \mathrm{~mL}$ supernatant and mixed thoroughly. Take $100 \mu \mathrm{L}$ diluted supernatant added with $1.8 \mathrm{~mL}$ phosphoric acid-EDTA buffer (pH 8.0) and $100 \mu \mathrm{L}$ orthophthalaldehyde $\left(1 \mathrm{mg} \mathrm{mL} \mathrm{m}^{-1}\right)$. After thorough mixing and incubation at room temperature for $15 \mathrm{~min}$ and fluorescence was determined at $420 \mathrm{~nm}$. Results were expressed as $\mu \mathrm{g} \mathrm{mg}^{-1} \mathrm{Pr}$.

\section{Glutathione Peroxidase (GPx) Activity}

Activity of GPx was measured by method of Rotruck et al. (1973). Added $200 \mu \mathrm{L}$ of $400 \mathrm{mM}$ Tris buffer (pH 7.0), $100 \mu \mathrm{L}$ of $10 \mathrm{mM}$ sodium azide $\left(\mathrm{NaN}_{3}\right), 200 \mu \mathrm{L}$ of $1 \mathrm{mM} \mathrm{GSH}$ and $100 \mu \mathrm{L}$ of $0.2 \mathrm{mM} \mathrm{H}_{2} \mathrm{O}_{2}$ to $200 \mu \mathrm{L}$ supernatant and mixed thoroughly at $37^{\circ} \mathrm{C}$ water bath for $10 \mathrm{~min}$; then added $0.4 \mathrm{~mL}$ of $10 \%$ TCA to end the reaction and collected the supernatant after centrifuging for $15 \mathrm{~min}$ at $3000 \mathrm{rpm}$. Added $0.5 \mathrm{~mL}$ Ellam solution $(19.8 \mathrm{mg}$ DTNB dissolved in $100 \mathrm{~mL}$ of $0.1 \%$ sodium nitrate $)\left(\mathrm{NaNO}_{3}\right)$ and $3.0 \mathrm{~mL}$ phosphoric acid-EDTA buffer ( $\mathrm{pH} 8.0)$ to $1.0 \mathrm{~mL}$ collected supernatant then recorded the absorbance at $412 \mathrm{~nm}$. One GPx activity unit was defined as the amount of enzyme required to deplete $1 \mu \mathrm{M}$ GSH in per mg protein per minute and results were expressed as $\mathrm{U} \mathrm{mg}^{-1} \mathrm{Pr}$.

\section{Malondialdehyde (MDA) Content}

Malondialdehyde (MDA) content was measured by method of TBA (2-thiobarbituric acid) colorimetry improved by Luo et al. (2006). Add $200 \mu \mathrm{L}$ supernatant, $0.2 \mathrm{~mL}$ of $8.1 \%$ sodium laurylsulfonate, $1.5 \mathrm{~mL}$ of $20 \%$ acetic acid buffer $(\mathrm{pH} 3.5)$, $1.5 \mathrm{~mL}$ of $1 \% \mathrm{TBA}$ and $1 \mathrm{~mL}$ distilled water in order and mixed thoroughly at $95^{\circ} \mathrm{C}$ water bath for $80 \mathrm{~min}$ then cooled and centrifuged for $15 \mathrm{~min}$ at $3000 \mathrm{rpm}$. Collected the supernatant and recorded the absorbance at $532 \mathrm{~nm}$. MDA content is expressed as the amount of TBARS contained in per mg protein and results were expressed as nmol $\mathrm{mg}^{-1} \mathrm{Pr}$.

Total protein content in tissues was estimated by method of Bradford (1976). The absorbance was recorded at $595 \mathrm{~nm}$ with bovine serum protein (BSA) as the standard protein. All measurements above were performed with UNICO ultravioletvisible spectrophotometer (UNICO WFZ UV-2802PC/PCS; Shanghai, China).

\section{Acetylcholinesterase (AChE) Activity}

Activity of AChE was measured following the methodology first described by Ellman et al. (1961) and adapted to 96well microplates. $400 \mu \mathrm{L}$ supernatant was added to a cuvette containing $2.6 \mathrm{~mL}$ of phosphate buffer ( $\mathrm{pH}$ 8.0, 0.1 M). Samples absorbance was read at $412 \mathrm{~nm}$, every minute during $10 \mathrm{~min}$. AChE activity was measured considering that one unit of enzyme is responsible for the formation of $1.0 \mathrm{nmol}$ of thiocholine per minute. Results were expressed as $\mathrm{U} \mathrm{mg}^{-1} \mathrm{Pr}$.

\section{TCTP, GST3, Hsp70, Hsp27 mRNA Expression}

Total RNA was extracted from Pseudosciaena crocea using the Trizol reagent (Invitrogen, United States) according to the manufacturer's directions. Total RNA was incubated with RQ1 RNase-free DNase (Promega, United States) to remove the contaminating genomic DNA. cDNA was transcribed from $1 \mathrm{mg}$ of total RNA using SuperScript III kit (Invitrogen, United States) according to the manufacturer's guide. TCTP, GST3, Hsp70, Hsp27 mRNA expression levels were determined using the ABI PRISM 7000 Fluorescent Quantitative PCR System (Applied Biosystems, United States) with the $\beta$-actin gene as a reference gene. Quantitative real-time polymerase chain reaction (qPCR) was performed in a total volume of $50 \mu \mathrm{L}$ containing $25 \mu \mathrm{L}$ of 
SYBR Green PCR Master Mix, $1 \mu \mathrm{L}$ of a mixture of forward and reverse primers $(10 \mu \mathrm{mol} / \mathrm{L}), 4 \mu \mathrm{L}$ of nuclease free water and $20 \mu \mathrm{L}$ of the diluted cDNA templates. The qPCR cycles were as follows: $65^{\circ} \mathrm{C}$ for $2 \mathrm{~min}, 95^{\circ} \mathrm{C}$ for $10 \mathrm{~min}$ followed by 40 cycles of $95^{\circ} \mathrm{C}$ for $15 \mathrm{~s}$ and $65^{\circ} \mathrm{C}$ for $1 \mathrm{~min}$. All qPCR reactions were performed in triplicate. At the end of each $\mathrm{qPCR}$ reaction, dissociation curve analysis of the amplification products was carried out to confirm that only one PCR product was amplified. The $2^{-\Delta \Delta C T}$ method was employed to calculate the relative mRNA expression level of the TCTP, GST3, Hsp70, Hsp27 mRNAs. The $\beta$-actin gene was constitutively expressed at constant level before and after $\mathrm{MeHg}$ treatment, indicating the stability of the reference gene. The primers were listed in Table $\mathbf{1}$.

\section{Data Treatment and Statistical Analyses}

The results of the experiment were expressed as Means \pm standard deviation (means \pm SD), KolmogorovSmirnov test and Levene test were used to test the hypothesis of normality and homogeneity respectively. If the data satisfied both normality and homogeneity, one-way ANOVA and Dunnett's multiple comparison method were used to analyze the significant differences between groups. If either of the two assumptions was not satisfied, the data would be converted logarithmically and then the ANOVA and multiple comparisons would be performed. All statistical analysis was carried out with SPSS software (SPSS 15.0, Chicago, IL, United States) and significance level of $p<0.05$ was used for all tests. Software SigmaPlot 12.5 was used to do figure processing.

\section{RESULTS}

\section{Effects on Antioxidants in the Tissues of Pseudosciaena crocea}

After exposed to $\mathrm{MeHg}$ for 30 days, the SOD activity of large yellow croaker juveniles was significantly inhibited (ANOVA, $p<0.05$ ), it was $33.9,35.8$, and $29.2 \%$ lower in the $0.25,1.0$, and $4.0 \mu \mathrm{g} \mathrm{L}^{-1}$ groups than in the control, respectively (Dunnett's test, $p<0.05$; Figure 1A). The CAT activity of juvenile fish was also significantly affected by $\mathrm{MeHg}$ exposure, it was $87.7 \%$ higher in the $4.0 \mu \mathrm{g} \mathrm{L}^{-1} \mathrm{MeHg}$ treatment group with respect to the control (ANOVA Dunnett's test, $p<0.05$; Figure 1B).

The GSH content of juvenile was significantly induced by MeHg exposure (ANOVA, $p<0.05$ ), and results showed that GSH content in $4.0 \mu \mathrm{g} \mathrm{L}^{-1}$ group increased by $121.5 \%$ compared with that in the control group (ANOVA, Dunnett's test, $p<0.05$; Figure 2A). GPx activity was also significantly induced (ANOVA, $p<0.05)$, GPx activity in the 1.0 and $4.0 \mu \mathrm{g} \mathrm{L}^{-1}$ groups increased by 34.5 and $82.7 \%$ than control after 30 days $\mathrm{MeHg}$ exposure (Dunnett's test, $p<0.05$; Figure 2B). As for the MDA content, it was 56.3 and $53.5 \%$ higher in the 1.0 and 4.0 treatments than that in the control group, respectively (ANOVA Dunnett's test, $p<0.05$; Figure 2C).

Acetylcholinesterase activity was significantly affected by 30 days of $\mathrm{MeHg}$ exposure (ANOVA, $p<0.05$ ). It decreased by $18.3,25.2$, and $21.7 \%$ in the $0.25,1.0$, and $4.0 \mu \mathrm{g} \mathrm{L}^{-1}$ group respectively comparing with the control (Dunnett's test, $p<0.05$; Figure 3).

\section{Expression Profiles of TCTP, GST3, Hsp70, Hsp27 in Pseudosciaena crocea After Exposed to MeHg}

Quantitative real-time polymerase chain reaction was performed to measure the expression of TCTP, GST3, Hsp70, Hsp27, transcripts in muscle with $\beta$-actin employed as the normalization gene. The mRNA expression levels of TCTP, GST3, Hsp70, Hsp27 were all significantly up-regulated in Pseudosciaena crocea in a dose-dependent manner after treatment of $\mathrm{MeHg}$ (Figures 4, 5, 6A,B).

\section{DISCUSSION}

\section{Antioxidant Defense}

Antioxidants as well as free radical scavengers levels have been proved to be closely related with various stressors including metals (Aliko et al., 2018). The first reaction to ambient pressure is oxidative stress and it usually occurs when the ROS level exceeds the scavenging activities of antioxidant molecules (Maharajan et al., 2018). Pollutants including MeHg were thought to be effective inducer for ROS formation in organisms (do Nascimento et al., 2008). Previous studies indicated that this event closely related to cell energy metabolism dysfunction and electron transport chain disruption (do Nascimento et al., 2008). Excessive ROS production could cause the decrease of mitochondrial membrane, which may lead to the oxidation of polyunsaturated fatty acids of membrane and produce a large amount of lipid peroxidation (Yin et al., 2007).

SOD is the enzyme that catalyze $\mathrm{O}_{2}^{-}$and $\mathrm{H}^{+}$to less toxic $\mathrm{H}_{2} \mathrm{O}_{2}$ and $\mathrm{O}_{2}$ while CAT converts $\mathrm{H}_{2} \mathrm{O}_{2}$ into $\mathrm{H}_{2} \mathrm{O}$ (Maharajan et al., 2018), thus to prevent oxidative stress and maintain cell homeostasis (Mansour and Mossa, 2009). Therefore, the SODCAT system provide the first line of defense against ROS damage in organisms (Liu et al., 2015). Previous research suggested that the activity of SOD could be activated to dispel the increased ROS in cells (Zhao et al., 2013). In the present study, SOD activity was inhibited by $\mathrm{MeHg}$ exposure, this phenomenon was probably due to the antioxidant failed to dispel the excessive ROS induced by MeHg. Similar results was also reported in liver and brain of seabass (Dicentrarchus labrax) by MeHg exposure (Maulvault et al., 2017). MeHg could induce a reduction of activity in enzymes related to mitochondrial energy metabolism including SOD, which could be explained by $\mathrm{MeHg}$ may impair the function of mitochondria when the organelle exhibits a membrane permeability transition state (do Nascimento et al., 2008). However, opposite results were found in liver and kidney of Atlantic salmon (Salmo salar) parr and zebrafish (Danio rerio) which indicated an adaptive reaction to neutralize oxidative stress was induced by $\mathrm{MeHg}$ exposure (Berntssen et al., 2003; Strungaru et al., 2018). Moreover, SOD activity may change with the exposure concentration, for example, increased SOD activity was found in the brain of Atlantic salmon (Salmo salar) parr by 
TABLE 1 | Primers used in the experiment.

\begin{tabular}{lll}
\hline Primer name & Primer sequence $\left(\mathbf{5}^{\prime} \mathbf{-} \mathbf{3}^{\prime} \mathbf{)}\right.$ & Purpose \\
\hline TCTP-F & CAAAGCGCCAACATGATCAT & RT-PCR and quantitative \\
TCTP-R & CACCTGGTATGACTTCTTGTGTA & Real-time PCR \\
GST3-F & CCCTCTGAACTAATACAAAATCA & GCTCTAACGCCATCGTTGTCTGC \\
GST3-R & ACACTCCTCTACAGCCATGA \\
Hsp27-F & CAGCTCCTCGGGTGAAAGTGGT \\
Hsp27-R & GAGACTGCGGGTGGAGTATG \\
Hsp70-F & TGGCTCTCTCACCCTCATACAC \\
Hsp70-R & TATGAAGGCTATGCCCTGCC \\
$\beta-A c t i n-F$ & TGAAGGAGTAGCCACGCTCTGT \\
$\beta-A c t i n-R$ &
\end{tabular}
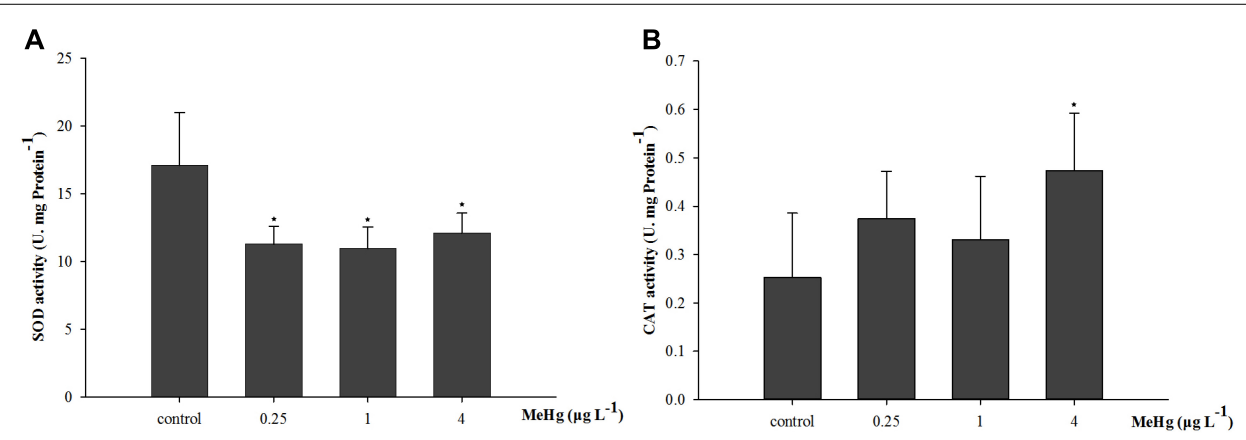

FIGURE 1 | Changes of (A) SOD activity, and (B) CAT activity in Pseudosciaena crocea under 30 days exposure to MeHg (U mg ${ }^{-1} \mathrm{Pr}$, value represent means $\pm \mathrm{SD}), n=4$, asterisks represent statistically significant differences compared with the control $(* p<0.05)$.

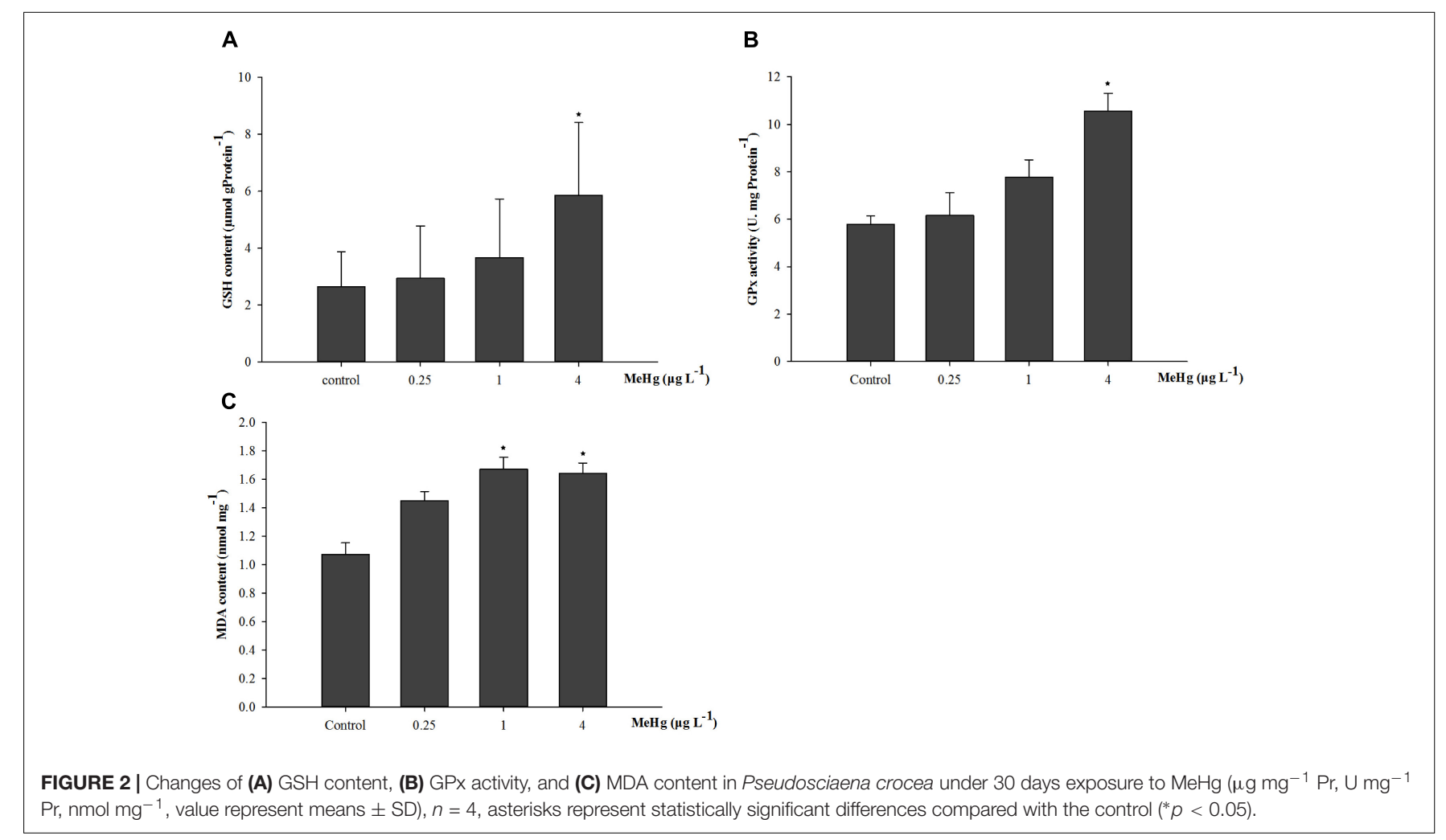



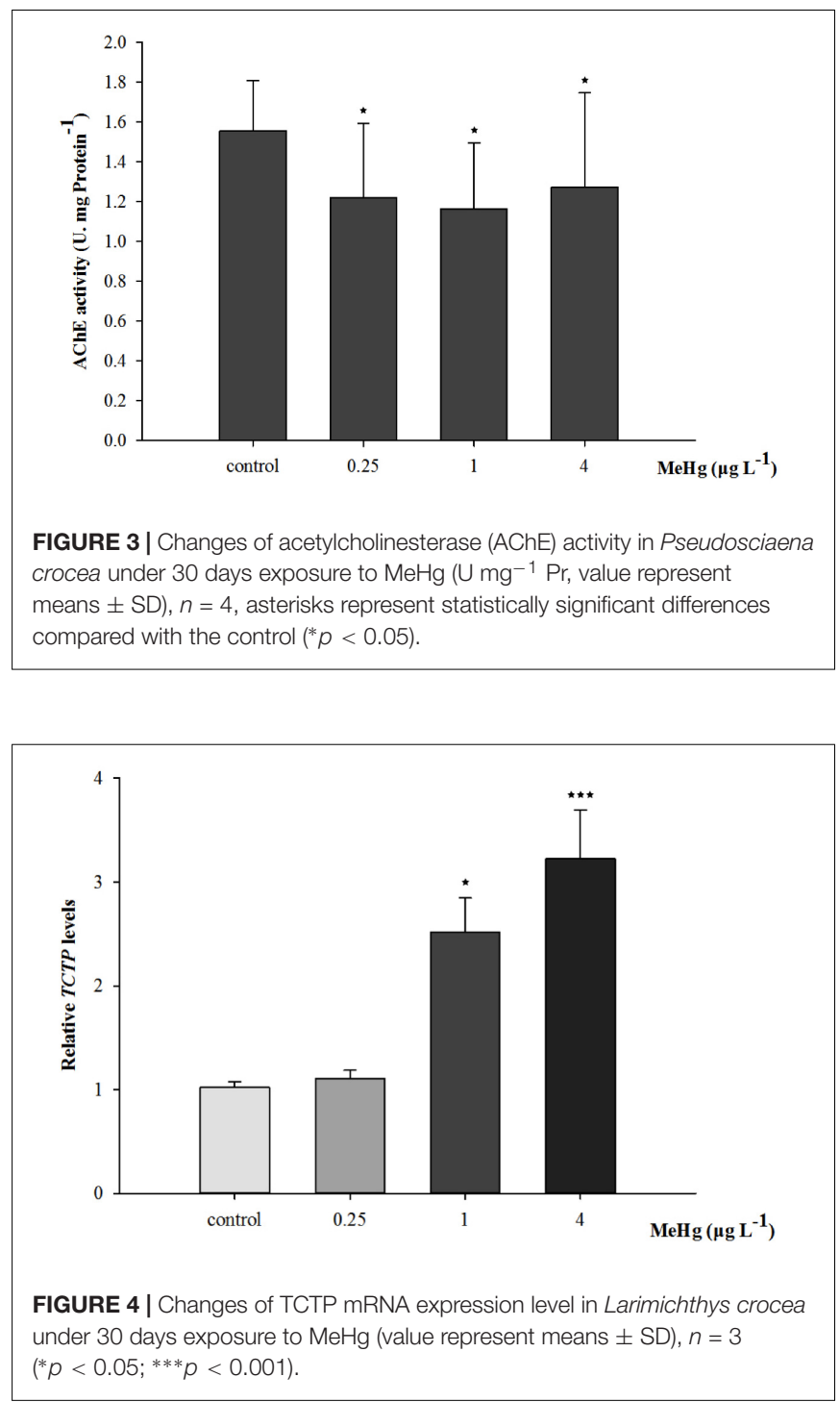

$5 \mathrm{mg} \mathrm{MeHg} / \mathrm{kg}$ exposure, but with the concentration increased to $10 \mathrm{mg} \mathrm{MeHg} / \mathrm{kg}$ decreased activity occurred (Berntssen et al., 2003). This result may explained by the brain is a relatively susceptible organ to oxidative injury compared with liver and kidney, and the redox defense system in the brain is more easier to break-down after higher concentration of $\mathrm{MeHg}$ exposures (Berntssen et al., 2003).

The induction of CAT activity observed in the present study may be related to oxidative stress leading to the continuous generation of $\mathrm{H}_{2} \mathrm{O}_{2}$ by $\mathrm{O}_{2}^{-}$, and activated CAT activity could protect the organism by scavenging $\mathrm{H}_{2} \mathrm{O}_{2}$. This was consistent with liver and muscle of juveniles seabass (Dicentrarchus labrax) exposed to MeHg (Maulvault et al., 2017). Similarly, the gene expression of cat was also found to be up-regulated by $\mathrm{MeHg}$ exposure in glass eel (Anguilla anguilla) (Claveau et al., 2015). On the contrary, inhibited CAT activity was found in zebrafish (Danio rerio) larvae by mercury chloride exposure (Cruz et al., 2013). Such various results in previous studies indicated that

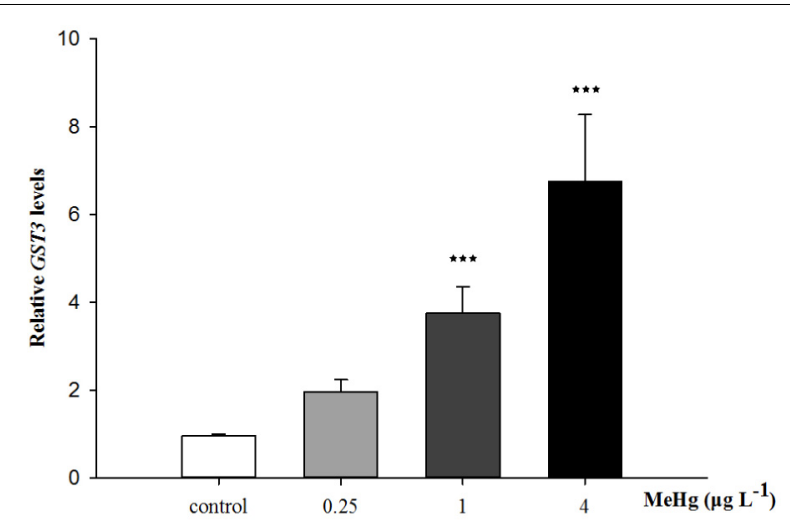

FIGURE 5 | Changes of GST3 mRNA expression level in Larimichthys crocea under 30 days exposure to $\mathrm{MeHg}$ (value represent means $\pm \mathrm{SD}$ ), $n=3$ $(* * * p<0.001)$.

activity of SOD and CAT responded differently to mercuryrelated exposure in different species and different life stages, some species showing increased activity while others exhibiting inhibited activity or no responses (Cao et al., 2010). In addition, various responses of antioxidant enzymes are also related with concentration of $\mathrm{MeHg}$, exposure time and environmental factors such as temperature, etc. (Huang et al., 2010a).

Glutathione is thought to be one of the most important nonprotein thiols in organisms' cell and tissue (Hoguet and Key, 2007). It has the potential to prevent cellular components damage caused by free radicals (Pompella and Corti, 2003). GSH-redox system is known to be a key antioxidant defense in protecting cells from oxidative damage as well as detoxification (Lee et al., 2017b). Several studies reported decreased GSH level by MeHg exposure, for example, decreased GSH was observed in liver of rainbow trout (Oncorhynchus mykiss) and copepod (Tigriopus japonicus) by $\mathrm{MeHg}$ exposure, which could be explained by the formation of $\mathrm{MeHg}-\mathrm{GSH}$ complex by interaction of $\mathrm{MeHg}$ with GSH through its $\mathrm{SH}$ group or enhanced oxidation of this thiol (Mozhdeganloo et al., 2015; Lee et al., 2017a). In addition, changes of expression levels of genes related to GSH metabolism in brain of female zebrafish (Danio rerio) reflects $\mathrm{MeHg}$ exposure may lead to the metabolic dysfunction of GSH (Richter et al., 2011). However, in the present study, GSH content was increased after 30 days of $\mathrm{MeHg}$ exposure. Similar results was also found in liver of matrinxa (Brycon amazonicus) exposed to mercury chloride which could be explained by the fish gut could protect themself from oxidative damage through enhance uptake of amino acid substrates and the biosynthetic enzymes related to GSH synthesis when encounter mercury exposure (Monteiro et al., 2010). In summary, the alteration of GSH content and metabolism are of vital importance in protecting organisms against oxidative stress induced by $\mathrm{MeHg}$.

GPx could convert hydroperoxides into hydroxyl compounds with GSH as substrate and its main detoxification function is to terminate the propagation of the radical chain, thus protecting membranes from oxidative damage (Maharajan et al., 2018). As an effective antioxidant defense system of oxidative stress 

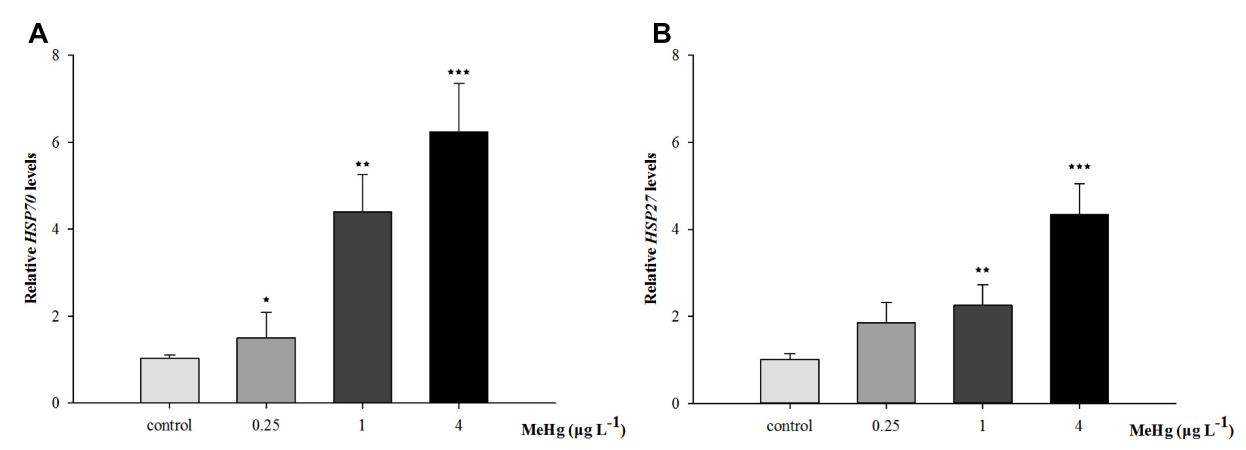

FIGURE 6 | (A) Hsp70, (B) Hsp27 mRNA expression level in (Larimichthys crocea) after expose to various doses of MeHg. The results are shown as value represent means $\pm S D(n=3),{ }^{*} p<0.05 ;{ }^{* *} p<0.01 ;{ }^{* * *} p<0.001$.

induced by $\mathrm{MeHg}$, the increased GPx activity is associated with a compensatory response of SOD activities (Lee et al., 2017a). Therefore, significantly induced GPx activity in this study might indicate these molecules were participated in the detoxification of $\mathrm{H}_{2} \mathrm{O}_{2}$ produced in juveniles. This result is consist with copepod (Tigriopus japonicus) exposed to $\mathrm{MeHg}$ (Lee et al., 2017a). On the other hand, in the rotifer (Brachionus koreanus), the GPx activity was inhibited when exposed to low concentration of $\mathrm{MeHg}$ (1 and $10 \mathrm{ng} / \mathrm{L}$ ), but increased GPx activity was observed with the concentration increased (100 ng/L) (Lee et al., 2017b).

Malondialdehyde is the product of lipid peroxidation formed by lipoperoxidation reaction of oxygen free radicals, phospholipids in biofilm and lipoperoxidation of macro molecules such as side chains of polyunsaturated fatty acids and nucleic acids associated with enzymes and membrane receptors (Uner et al., 2001). Expose to exogenous pollutants could induce a large number of MDA and its content could directly reflect the level of oxidative stress, so it is an important index to evaluate the degree of oxidative damage in cells (Mozhdeganloo et al., 2015). In the present study, MDA content of juveniles was significantly induced by $\mathrm{MeHg}$ exposure. Increased MDA were also reported in zebrafish (Danio rerio) and rainbow trout (Oncorhynchus mykiss) by MeHg exposure (Mozhdeganloo et al., 2015; Strungaru et al., 2018). The results suggested that although the antioxidant synthesized of large yellow croaker was induced to some extent by $\mathrm{MeHg}$ exposure, but it was not sufficient to eliminate the large amount of ROS produced. The degree of lipid peroxidation was aggravated which might exceed the ability of anti-oxidation and defense in large yellow croaker, aggravate the degree of oxidative damage in tissues and finally caused a series of metabolic and functional disorders, which had a toxic effect on cells.

\section{AChE Activity}

The toxicity of $\mathrm{MeHg}$ mainly targets at CNS, it alters the biochemical and ultrastructure of both astrocytes and neurons (Lee et al., 2017b). Previous researches showed that the developing CNS is more sensitive to several contaminants than the adult CNS (Farina et al., 2011). MeHg affects the cerebral cortex, visual, auditory, somatic sensory, and motor cortex, as well as the hippocampus and the granule layer of the cerebellum in the adult brain, thus causing a remarkable loss of neurons in these brain regions (Carta et al., 2003). However, due to the high sensitivity of the immature CNS in the developing brain, a widespread neuronal loss is more easier to occur (do Nascimento et al., 2008). As an important enzyme in nervous system, AChE could hydrolyze the neurotransmitter acetylcholine (ACh), and AChE activity is widely used in assessment of neurotoxic stress induced by pollutants (Hoguet and Key, 2007). In the present study, AChE activity was inhibited by $\mathrm{MeHg}$ exposure, similar results was also observed in juveniles of seabass (Dicentrarchus labrax), since MeHg might be strongly combined with the AChE receptor, thus blocking the electric signals between neurons and target cells (Maulvault et al., 2017). Inhibited AChE activity in the present study may indicate the neurotoxicity caused by $\mathrm{MeHg}$. However, further research about juveniles behavior, histology and biochemical analysis of brain are still needed to clarify the neurotoxicity induced by $\mathrm{MeHg}$ exposure.

\section{Gene Expressions Related to Immune Response}

Parental compounds of environmental contaminants, their metabolites or indirectly generation of ROS may result in DNA damage in organisms (Oliveira et al., 2009). In order to investigate the immune response in detail, the mRNA expression of essential proteins related to antioxidant enzymes were investigated. TCTP is a highly conserved multifunctional protein which is usually highly expressed in tumor cells with activities ranging from cytoskeletal to transcription regulation in organisms (Liu et al., 2018). It also regulates the innate immune response, especially the inflammatory to neutralize infectious substances and initiate repair to the injured tissue (Jia et al., 2017). Accumulating evidence indicated that TCTP also participated in the anti-stress responses in invertebrate (Jia et al., 2017). For instance, in nematode (Brugia malayi), BmTCTP could serve as an anti-apoptotic protein and protect cells from oxidative damage (Gnanasekar and Ramaswamy, 2007). TCTP was also an anti-metal stress factor, for instance MgTCTP of the mussel (Mytilus galloprovincialis) could participated in the regulation of cadmium stress (You et al., 2013). In the 
present study, TCTP expression level was significantly upregulated in a dose-dependent manner after $\mathrm{MeHg}$ treatment which indicate that adaptive immune response to stress may be caused by MeHg. This result is consistent with crustacean (Eriocheir sinensis) by copper exposure, since heavy metal ions may be accumulated in tissues, and the synthesis of TCTP increases correspondingly with the increase of ions (Wang et al., 2011). In the future, the specific molecular mechanisms underlying the response of TCTP to stressors such as heavy metal require to be revealed, especially whether this gene can be applied as a molecular biomaker in ecotoxicological studies.

Glutathione $S$-transferase (GSTs), a widely expression protein that can be found in various tissues, possesses detoxification and antioxidation abilities and plays an important role in immune and biotransformation (Leiers et al., 2003). One of the major functions of GSTs is to catalyze toxic electrophilic compounds to react readily with endogenous $\mathrm{GSH}$, thereby protecting other electrophilic centers (e.g., DNA and proteins, etc.) from being damaged (Hayes and McLellan, 1999). Previous studies suggested that GSTs could serve as sensor for oxidative stress in response to environmental contaminants including metals (Lee et al., 2017a). In this study, after 30 days of $\mathrm{MeHg}$ exposure, the enhanced expression of GST3 indicated the response of cells to oxidative stress and this result is also matched with the increased GSH content. Similarly, most of the mRNA levels of antioxidantrelated genes, including GSTs,were also up-regulated by $\mathrm{MeHg}$ exposure in a concentration-dependent manner in Brachionus koreanus (Lee et al., 2017a). Furthermore, in Atlantic cod (Gadus morhua), GSTs are involved in consistently up-regulated genes induced by $\mathrm{MeHg}$ which suggested the increasing synthesis of antioxidants (Yadetie et al., 2013). Thus, mRNA expression level of GST3 also have the potential to be used as a sensitive biomarker for $\mathrm{MeHg}$ exposure.

The Hsp70 proteins are critical for protein folding and protecting cells from stress, its production is correlated with thermal stress like high temperatures and metals including cadmium, copper, mercury, etc. (Rajeshkumar and Munuswamy, 2011). Studies found that certain Hsp genes including Hsp70 can act as biomakers by contaminants exposure (Yadetie et al., 2013). As a pleiotropic inhibitor of apoptotic cell death, the protective effect of HSP27 is mainly in stressed cells (Bruey et al., 2000). Hsp27 can enhance the antioxidant activities by increasing GSH content. Moreover, it could activate protein kinase B/Akt, and Akt was cell-death inhibitor which can phosphorylate and inactivate the procaspase- 9 or prevent the release of cytochrome $\mathrm{C}$ from mitochondria, thus reducing the cell death (Mehlen et al., 1996; Konishi et al., 1997; Kennedy et al., 1999). In the present study, the mRNA expression levels of Hsp70, Hsp27 was significantly up-regulated after treatment of MeHg. Similarly, up-regulation of HSP70 was also observed in liver of Atlantic cod (Gadus morhua) suggesting the adaptive responses to $\mathrm{MeHg}$ toxicity (Yadetie et al., 2013).

\section{CONCLUSION}

It changes in enzymes activity and mRNA expressions related to immune response and oxidative stress indicated that $\mathrm{MeHg}$ can induce oxidative stress in tissues of large yellow croaker juveniles. Moreover, decreased AChE activity shows MeHg may also induce neurotoxicity effects to fish. On the other hand, the results also suggested that large yellow croaker juveniles have the inherent potential to regulate the levels of antioxidants such as SOD, CAT, $\mathrm{GSH}$, etc. and initiate immune response in order to protect fish to some extent from oxidative stress induced by $\mathrm{MeHg}$. Toxic effects under sub-lethal concentration of contaminants often reflect the ecological, physiological, biochemical, histopathological, or behavioral changes of biota. These responses tend to be latent, but may reduce the ability of organisms to survive, reproduce and compete in natural environment. Since these reactions are not easy to detect, the effects on biological populations are severe. In the future study, we will pay more attention to the behavior and histopathology change of fish tissues thus to know more about how fish juveniles responded to heavy metals. Moreover, this research could offer important information to the development of water quality standards in habitat of large yellow croaker in China.

\section{AUTHOR CONTRIBUTIONS}

WH designed the experiment. $\mathrm{WH}$ and FW analyzed the experimental results and wrote the manuscript. XiX, QL, XuX, and JZ helped in correcting the first and final manuscript. LC and $\mathrm{JH}$ helped in writing and revising the final manuscript. YG and SJ helped in keeping the juveniles' samples and recorded the results of the experiment. All authors have given approval to the final version of the revised manuscript.

\section{FUNDING}

This work was financially supported by the National Marine Public Welfare Research Project of China (Grant No. 201405007), the National Natural Science Foundation of China (Grant Nos. 41306112, 41406167, and 21307019), the China-APEC Cooperation Fund (Grant No. 2029901), the Science and Technology Support Program of China (Grant No. 2015BAD08B01), and the Basic Scientific Research of SIO, China (Grant Nos. JG1717 and JG1526).

\section{ACKNOWLEDGMENTS}

We thank Prof. Wu X. F. and Prof. Jiao H. F. for their help in providing facilities and conveniences for the present study. 


\section{REFERENCES}

Aliko, V., Qirjo, M., Sula, E., Morina, V., and Faggio, C. (2018). Antioxidant defense system, immune response and erythron profile modulation in goldfish, Carassius auratus, after acute manganese treatment. Fish Shellfish Immun. 76, 101-109. doi: 10.1016/j.fsi.2018.02.042

Arleny, I., Tabouret, H., Rodriguez-Gonzalez, P., Bareille, G., Donard, O. F., and Amouroux, D. (2007). Methylmercury bioconcentration in muscle tissue of the European eel (Anguilla anguilla) from the Adour estuary (Bay of Biscay, France). Mar. Pollut. Bull. 54, 1031-1036. doi: 10.1016/j.marpolbul.2007.04.004

Aschner, M. (1989). Brain, kidney and liver 203Hg-methyl mercury uptake in the rat: relationship to the neutral amino acid carrier. Pharm. Toxicol. 65, 17-20. doi: 10.1111/j.1600-0773.1989.tb01119.x

Beers, R. F., and Sizer, I. W. (1952). A spectrophotometric method for measuring the breakdown of hydrogen peroxide by catalase. J. Biol. Chem. 195, 133-140.

Berntssen, M. H., Aatland, A., and Handy, R. D. (2003). Chronic dietary mercury exposure causes oxidative stress, brain lesions, and altered behaviour in Atlantic salmon (Salmo salar) parr. Aquat. Toxicol. 65, 55-72. doi: 10.1016/S0166445X(03)00104-8

Bradford, M. M. (1976). A rapid and sensitive method for the quantitation of microgram quantities of protein utilizing the principle of protein-dye binding. Anal. Biochem. 72, 248-254. doi: 10.1016/0003-2697(76)90527-3

Bruey, J. M., Ducasse, C., Bonniaud, P., Ravagnan, L., Susin, S. A., DiazLatoud, C., et al. (2000). Hsp27 negatively regulates cell death by interacting with cytochrome C. Nat. Cell Biol. 2, 645-652. doi: 10.1038/35023595

Cambier, S., Bénard, G., Mesmer-Dudons, N., Gonzalez, P., Rossignol, R., Brèthes, D., et al. (2009). At environmental doses, dietary methyl mercury inhibits mitochondrial energy metabolism in skeletal muscles of the zebrafish (Danio rerio). Int. J. Biochem. Cell Biol. 41, 791-799. doi: 10.1016/j.biocel.2008. 08.008

Cao, L. A., Huang, W., Liu, J. H., Yin, X. B., and Dou, S. Z. (2010). Accumulation and oxidative stress biomarkers in Japanese flounder larvae and juveniles under chronic cadmium exposure. Comp. Biochem. Phys. C Toxicol. Pharm. 151, 386-392. doi: 10.1016/j.cbpc.2010.01.004

Carta, P., Flore, C., Alinovi, R., Ibba, A., Tocco, M. G., Aru, G., et al. (2003). Sub-clinical neurobehavioral abnormalities associated with low level of mercury exposure through fish consumption. Neurotoxicology 24, 617-623. doi: 10.1016/ S0161-813X(03)00080-9

Claveau, J., Monperrus, M., Jarry, M., Baudrimont, M., Gonzalez, P., Cavalheiro, J., et al. (2015). Methylmercury effects on migratory behaviour in glass eels (Anguilla anguilla): an experimental study using isotopic tracers. Comp. Biochem. Phys. C Toxicol. Pharm. 171, 15-27. doi: 10.1016/j.cbpc.2015.03.003

Cruz, F. F., Leite, C. E., Pereira, T. C. B., Bogo, M. R., Bonan, C. D., Battastini, A. M. O., et al. (2013). Assessment of mercury chloride-induced toxicity and the relevance of P2X7 receptor activation in zebrafish larvae. Comp. Biochem. Physiol. Toxicol. Pharmacol. 158, 159-164. doi: 10.1016/j.cbpc.2013.07.003

Devlin, E. W. (2006). Acute toxicity, uptake and histopathology of aqueous methyl mercury to fathead minnow embryos. Ecotoxicology 15, 97-110. doi: 10.1007/ s10646-005-0051-3

Devlin, E. W., and Mottet, N. K. (1992). Embryotoxic action of methyl mercury on coho salmon embryos. Bull. Environ. Contam. Toxicol. 49, 449-454. doi: 10.1007/BF01239651

do Nascimento, J. L., Oliveira, K. R., Crespolopez, M. E., Macchi, B. M., Maués, L. A., Pinheiro, M. C., et al. (2008). Methylmercury neurotoxicity \& antioxidant defenses. Indian J. Med. Res. 128, 373-382.

Ellman, G. L., Courtney, K. D., Andresj, V. Jr., and Featherstone, R. M. (1961). A new and rapid colorimetric determination of acetylcholinesterase activity. Biochem. Pharmcol. 7, 88-95. doi: 10.1016/0006-2952(61) 90145-9

Farina, M., Rocha, J. B., and Aschner, M. (2011). Mechanisms of methylmercuryinduced neurotoxicity: evidence from experimental studies. Life Sci. 89, $555-$ 563. doi: 10.1016/j.lfs.2011.05.019

Fitzgerald, W. F., and Mason, R. P. (1997). Biogeochemical cycling of mercury in the marine environment. Met. Ions Biol. Syst. 80, 53-111.

Fu, X. W., Feng, X. B., Zhang, G., Xu, W. H., Li, X. D., Yao, H., et al. (2010). Mercury in the marine boundary layer and seawater of the South China Sea: concentrations, sea/air flux, and implication for land outflow. J. Geophys. Res. 115, 620-631. doi: 10.1029/2009JD012958
Gnanasekar, M., and Ramaswamy, K. (2007). Translationally controlled tumor protein of Brugia malayi, functions as an antioxidant protein. Parasitol. Res. 101, 1535-1540. doi: 10.1007/s00436-007-0671-z

Hayes, J. D., and McLellan, L. I. (1999). Glutathione and glutathione-dependent enzymes represent a co-ordinately regulated defence against oxidative stress. Free Radical Res. Commun. 31, 273-300. doi: 10.1080/10715769900300851

Hissin, P. J., and Hilf, R. (1976). A fluorometric method for determination of oxidized and reduced glutathione in tissues. Anal. Biochem. 74, 214-226. doi: 10.1016/0003-2697(76)90326-2

Hoguet, J., and Key, P. B. (2007). Activities of biomarkers in multiple life stages of the model crustacean, Palaemonetes pugio. J. Exp. Mar. Biol. Ecol. 353, 235-244. doi: 10.1016/j.jembe.2007.09.011

Huang, W., Cao, L., Shan, X. J., Xiao, Z. Z., Wang, Q. Y., and Dou, S. Z. (2010a). Toxic effects of zinc on the development, growth, and survival of red sea bream Pagrus major embryos and larvae. Arch. Environ. Contam. Toxicol. 58, 140-150. doi: 10.1007/s00244-009-9348-1

Huang, W., Cao, L., Ye, Z. J., Yin, X. B., and Dou, S. Z. (2010b). Antioxidative responses and bioaccumulation in Japanese flounder larvae and juveniles under chronic mercury exposure. Comp. Biochem. Phys. C Toxicol. Pharmacol. 152, 99-106. doi: 10.1016/j.cbpc.2010.03.005

Jia, Z., Wang, M., Yue, F., Wang, X., Wang, L., and Song, L. (2017). The immunomodulation of a maternal translationally controlled tumor protein (TCTP) in zhikong scallop Chlamys farreri. Fish Shellfish Immun. 60, 141-149. doi: 10.1016/j.fsi.2016.11.043

Kaur, P., Aschner, M., and Syversen, T. (2006). Glutathione modulation influences methyl mercury induced neurotoxicity in primary cell cultures of neurons and astrocytes. Neurotoxicology 27, 492-500. doi: 10.1016/j.neuro.2006.01.010

Kennedy, S. G., Kandel, E. S., Cross, T. K., and Hay, N. (1999). Akt/protein kinase $\mathrm{B}$ inhibits cell death by preventing the release of cytochrome $\mathrm{C}$ from mitochondria. Mol. Cell. Biol. 19, 5800-5810. doi: 10.1128/MCB.19.8.5800

Konishi, H., Matsuzaki, H., Tanaka, M., Takemura, Y., Kuroda, S., Ono, Y., et al. (1997). Activation of protein kinase B (Akt/RAC-protein kinase) by cellular stress and its association with heat shock protein Hsp27. FEBS Lett. 410, 493-498. doi: 10.1016/S0014-5793(97)00541-3

Lee, Y. H., Kang, H. M., Kim, D. H., Wang, M., Jeong, C. B., and Lee, J. S. (2017a). Adverse effects of methylmercury $(\mathrm{MeHg})$ on life parameters, antioxidant systems, and MAPK signaling pathways in the copepod Tigriopus japonicus. Aquat. Toxicol. 184, 133-141. doi: 10.1016/j.aquatox.2017.01.010

Lee, Y. H., Kim, D. H., Kang, H. M., Wang, M., Jeong, C. B., and Lee, J. S. (2017b). Adverse effects of methyl mercury $(\mathrm{MeHg})$ on life parameters, antioxidant systems, and MAPK signaling pathways in the rotifer Brachionus koreanus and the copepod Paracyclopina nana. Aquat. Toxicol. 190, 181-189. doi: 10.1016/j. aquatox.2017.07.006

Leiers, B., Kampkötter, A., Grevelding, C. G., Link, C. D., Johnson, T. E., and Henkle-Dührsen, K. (2003). A stress-responsive glutathione s-transferase confers resistance to oxidative stress in Caenorhabditis elegans. Free Radic. Biol. Med. 34, 1405-1415. doi: 10.1016/S0891-5849(03)00102-3

Liu, L., Zhu, B., Gong, Y. X., Liu, G. L., and Wang, G. X. (2015). Neurotoxic effect of triazophos on goldfish (Carassius auratus) and tissue specific antioxidant responses. Ecotoxicol. Environ. Saf. 116, 68-75. doi: 10.1016/j.ecoenv.2015. 03.001

Liu, Z. L., Xu, J., Ling, L., Zhang, R., Shang, P., and Huang, Y. P. (2018). CRISPR disruption of TCTP gene impaired normal development in the silkworm Bombyx mori. Insect Sci. 00, 1-10. doi: 10.1111/1744-7917.12567

Luo, Y., Su, Y., Lin, R. Z., Shi, H. H., and Wang, X. R. (2006). 2-chlorophenol induced ROS generation in fish Carassius auratus based on the epr method. Chemospheres 65, 1064-1073. doi: 10.1016/j.chemosphere.2006.02.054

Maharajan, K., Muthulakshmi, S., Nataraj, B., Ramesh, M., and Kadirvelu, K. (2018). Toxicity assessment of pyriproxyfen in vertebrate model zebrafish embryos (Danio rerio): a multi biomarker study. Aquat. Toxicol. 196, 132-145. doi: 10.1016/j.aquatox.2018.01.010

Mansour, S. A., and Mossa, A. T. H. (2009). Lipid peroxidation and oxidative stress in rat erythrocytes induced by chlorpyrifos and the protective effect of zinc. Pestic. Biochem. Physiol. 93, 34-39. doi: 10.1016/j.pestbp.2008.09.004

Marklund, S., and Marklund, G. (1974). Involvement of the superoxide anion radical in the auto oxidation of pyrogallol and a convenient assay for superoxide dismutase. Eur. J. Biochem. 47, 469-474. doi: 10.1111/j.1432-1033. 1974.tb03714.x 
Maulvault, A. L., Barbosa, V., Alves, R., Custódio, A., Anacleto, P., Repolho, T., et al. (2017). Ecophysiological responses of juvenile seabass (Dicentrarchus labrax) exposed to increased temperature and dietary methylmercury. Sci. Total Environ. 586, 551-558. doi: 10.1016/j.scitotenv.2017.02.016

Mehlen, P., Kretz-Remy, C., Préville, X., and Arrigo, A. P. (1996). Human HSP27, Drosophila HSP27 and human alphaB-crystallin expression-mediated increase in glutathione is essential for the protective activity of these proteins against tnfalpha-induced cell death. EMBO J. 15, 2695-2706. doi: 10.1002/j.1460-2075. 1996.tb00630.x

Monteiro, D. A., Rantin, F. T., and Kalinin, A. L. (2010). Inorganic mercury exposure: toxicological effects, oxidative stress biomarkers and bioaccumulation in the tropical freshwater fish matrinxã, Brycon amazonicus (Spix and Agassiz,1829). Ecotoxicology 19, 105-123. doi: 10.1007/s10646-0090395- 1

Morel, F. M. M., Kraepiel, A. M. L., and Amyot, M. (1998). The chemical cycle and bioaccumulation of mercury. Annu. Rev. Ecol. Syst. 29, 543-566. doi: 10.1146/ annurev.ecolsys.29.1.543

Mozhdeganloo, Z., Jafari, A. M., Koohi, M. K., and Heidarpour, M. (2015). Methylmercury -induced oxidative stress in rainbow trout (Oncorhynchus mykiss) liver: ameliorating effect of vitamin C. Biol. Trace Elem. Res. 165, 103-109. doi: 10.1007/s12011-015-0241-7

Oliveira, R., Domingues, I., Grisolia, C. K., and Soares, A. M. (2009). Effects of triclosan on zebrafish early-life stages and adults. Environ. Sci. Pollut. Res. 16, 679-688. doi: 10.1007/s11356-009-0119-3

Pompella, A., and Corti, A. (2003). Editorial: the changing faces of glutathione, a cellular protagonist. Biochem. Pharmacol. 66, 1499-1503. doi: 10.1016/S00062952(03)00504-5

Rajeshkumar, S., and Munuswamy, N. (2011). Impact of metals on histopathology and expression of Hsp 70 in different tissues of Milk fish (Chanos chanos) of Kaattuppalli island, South East Coast, India. Chemosphere 83, 415-421. doi: 10.1016/j.chemosphere.2010.12.086

Richter, C. A., Garcia-Reyero, N., Martyniuk, C., Knoebl, I., Pope, M., WrightOsment, K. M., et al. (2011). Gene expression changes in female zebrafish (Danio rerio) brain in response to acute exposure to methyl mercury. Environ. Toxicol. Chem. 30, 301-308. doi: 10.1002/etc.409

Rotruck, J. T., Pope, A. L., Ganther, H. E., Swanson, A. B., Hafeman, D. G., and Hoekstra, W. (1973). Selenium: biochemical role as a component of glutathione peroxidase. Science 179, 588-590. doi: 10.1126/science.179.4073.588

Samson, J. C., Goodridge, R., Olobatuyi, F., and Weis, J. S. (2001). Delayed effects of embryonic exposure of zebrafish (Danio rerio) to methyl mercury ( $\mathrm{MeHg}$ ). Aquat. Toxicol. 51, 369-376. doi: 10.1016/S0166-445X(00)00128-4

Squadrone, S., Benedetto, A., Brizio, P., Prearo, M., and Abete, M. C. (2015). Mercury and selenium in European catfish (Silurus glanis) from northern Italian rivers: can molar ratio be a predictive factor for mercury toxicity in a top predator? Chemosphere 119, 24-30. doi: 10.1016/j.chemosphere.2014. 05.052

Strungaru, S. A., Robea, M. A., Plavan, G., Todirascuciornea, E., Ciobica, A., and Nicoara, M. (2018). Acute exposure to methylmercury chloride induces fast changes in swimming performance, cognitive processes and oxidative stress of zebrafish (Danio rerio) as reference model for fish community. J. Trace Elem. Med. Biol. 47, 115-123. doi: 10.1016/j.jtemb.2018.01.019

Uner, N., Oruç, E. O., Canli, M., and Sevgiler, Y. (2001). Effects of cypermethrin on antioxidant enzyme activities and lipid peroxidation in liver and kidney of the freshwater fish, Oreochromis niloticus and Cyprinus carpio (L.). Bull. Environ. Contam. Toxicol. 67, 657-664. doi: 10.1007/s00128-001-0174-z

Wang, J. H., Qin, Y. T., Sun, Y. W., Wu, J. Y., and Cheng, X. S. (2005). The distribution and source of heavy metals in an important aquaculture sea area Xiangshan Bay. Mar. Fish. 27, 225-231.

Wang, Q., Fang, D. A., Li, W. W., Wang, J., and Jiang, H. (2011). A novel TCTP gene from the crustacean Eriocheir sinensis: possible role involving metallic $\mathrm{Cu}^{2+}$ stress. Biol. Bull. 221, 290-299. doi: 10.1086/BBLv221n3p290

Xia, C. H., Wu, X. G., Lam, J. C. W., Xie, Z. Q., and Lam, P. K. S. (2013). Methylmercury and trace elements in the marine fish from coasts of East China. Environ. Lett. 48, 1491-1501. doi: 10.1080/10934529.2013.796820

$\mathrm{Xu}$, K. D., and Liu, Z. F. (2007). The current stock of large yellow croaker Pseudosciaena crocea in the East China Sea with respects of its stock decline. J. Dalian Fish. Univ. 22, 392-396.

Yadetie, F., Karlsen, O. A., Lanzén, A., Berg, K., Olsvik, P., Hogstrand, C., et al. (2013). Global transcriptome analysis of Atlantic cod (Gadus morhua) liver after in vivo methylmercury exposure suggests effects on energy metabolism pathways. Aquat. Toxicol. 126, 314-325. doi: 10.1016/j.aquatox.2012.09.013

Yin, Z. B., Milatovic, D., Aschner, J. L., Syversen, T., Rocha, J. B. T., Souza, D. O., et al. (2007). Methylmercury induces oxidative injury, alterations in permeability and glutamine transport in cultured astrocytes. Brain Res. 1131, 1-10. doi: 10.1016/j.brainres.2006.10.070

You, L., Ning, X., Liu, F., Zhao, J., Wang, Q., and Wu, H. (2013). The response profiles of HSPA12A and TCTP from Mytilus galloprovincialis to pathogen and cadmium challenge. Fish Shellfish Immunol. 35, 343-350. doi: 10.1016/j.fsi.2013. 04.021

Zhang, L., and Wong, M. H. (2007). Environmental mercury contamination in China: sources and impacts. Environ. Int. 33, 108-121. doi: 10.1016/j.envint. 2006.06.022

Zhao, X., Wang, S., Wu, Y., You, H., and Lv, L. (2013). Acute ZnO nanoparticles exposure induces developmental toxicity, oxidative stress and DNA damage in embryo-larval zebrafish. Aquat. Toxicol. 136, 49-59. doi: 10.1016/j.aquatox. 2013.03.019

Conflict of Interest Statement: The authors declare that the research was conducted in the absence of any commercial or financial relationships that could be construed as a potential conflict of interest.

Copyright $\odot 2018 \mathrm{Wu}$, Huang, Liu, Xu, Zeng, Cao, Hu, Xu, Gao and Jia. This is an open-access article distributed under the terms of the Creative Commons Attribution License (CC BY). The use, distribution or reproduction in other forums is permitted, provided the original author(s) and the copyright owner(s) are credited and that the original publication in this journal is cited, in accordance with accepted academic practice. No use, distribution or reproduction is permitted which does not comply with these terms. 